MSSD Discussion Paper No. 27

\title{
Property Rights in a Flea Market Economy
}

\author{
by \\ Marcel Fafchamps* and Bart Minten \\ (*Stanford University)
}

Markets and Structural Studies Division

International Food Policy Research Institute 2033 K Street N.W.

Washington, D.C. 20006

Tel. (202)-862-5600 and Fax (202)-467-4439

\section{March 1999}

Contact: Carolyn Roper

Tel. (202) 862-8148 or Fax: (202) 467-4439 


\title{
Property Rights in a Flea Market Economy \\ Marcel Fafchamps ${ }^{\dagger}$ and Bart Minten ${ }^{\dagger \dagger}$
}

February 1999

\begin{abstract}
$^{1}$
This paper studies liberalized grain markets in Madagascar and examines how property rights are protected and contracts are enforced among agricultural traders. We find that the incidence of theft and breach of contract is low and that the losses resulting from such instances are small. This, however, does not result from reliance on legal institutions -- actual recourse to police and courts is fairly rare, except in cases of theft -- but from traders' reluctance to expose themselves to opportunism. As a result, Malagasy grain trade resembles a flea market, with little or no forward contracting and high transactions costs. The dominant contract enforcement mechanism is trust-based relationships. Trust is established primarily through repeated interaction with little role for referral by other traders. Information on bad clients does not circulate widely, hence severely limiting group punishments for non payment.
\end{abstract}

$\dagger$ Department of Economics, Stanford University; currently at DECRG, MC3-535, The World Bank, 1818 H Street N.W., Washington, D.C. 20433. Tel.: (202) 473-9174. Email: fafchamp@leland.stanford.edu. †† Department of Agricultural and Environmental Economics, Katholiek Universiteit van Leuven, Kardinaal Mercierlaan 92, 3001 Heverlee (Leuven), Belgium. Email: bart.minten@agr.kuleuven.ac.be

1 We benefitted from conversations and comments from Jean Claude Randrianarisoa and Eliane Ralison. Special thanks go to Ousmane Badiane for obtaining funding for this research. We acknowledge financial support for data collection from the United States Agency for International Development. 
Since North's $(1973,1990)$ seminal work on the development of capitalism in Europe, the fundamental role that market institutions play in economic growth has become increasingly recognized. In particular, North argued that individual property rights need to be protected from theft and embezzlement as well as from arbitrary expropriation by agents of the state. In addition, institutions such as lawyers and courts must exist that ensure compliance with contractual obligations and deter opportunistic breach of contract. These ideas have largely shaped the research and policy agenda for transition economies and developing countries alike (e.g., Benson (1990), Baer and Gray (1995), Hendley, Murrell and Ryterman (1998), McMillan (1996), Fafchamps (1996)). They have also spawn new and insightful research in the various forms that market institutions have taken over the course of human history (e.g., Ensminger (1992), Greif (1993, 1994), Milgrom, North and Weingast (1991)).

This paper studies whether institutions exist in present day Madagascar that protect property rights and ensure contract compliance among grain traders. Madagascar is a particularly suitable place to study market institutions at early stages of development because, until recently, grain trade was entirely under state control (e.g., Barrett (1997a, 1997b), Dorosh and Bernier (1994), Berg (1989)). At the same time, the island has kept much of the French legal code and judicial system that it inherited from colonisation. Malagasy commercial law may be a little dated, not having been overhauled since independence (e.g., Root (1993)). But it is likely to be quite superior to the legal environment that prevails in most transitional economies. Liberalized grain trade in Madagascar thus constitutes an interesting test case of the role of law per se in the development of efficient markets and it provides a unique window on the early development of markets when laws are adequate. An analysis of the functioning of Madagascar grain markets 
should therefore supply useful insights on the likely effect of legal reform in transition economies at a similar level of development.

Using data from a trader survey that we designed and collected ourselves, we show that the incidence of theft and breach of contract is low among Malagasy grain traders and that the losses resulting from such instances are small. At prima facie these results suggest that market institutions work well. A closer look at the evidence, however, reveals that low incidence of theft and contractual breach is achieved essentially through low exposure. Theft is rare because many traders do not stock the goods they sell and, if they do, they go to great length ensuring that their stocks are protected -- e.g., by sleeping in their store. Econometric analysis confirms that overnight storage is a significant risk factor in theft incidence. Among those to transport grain from town to town, payment of protection money and travel in convoy are common -- presumably against the risk of highway robbery that is endemic in certain parts of the country. Surveyed traders even declare refraining from hiring additional workers for fear of employee-related theft.

The situation regarding contract compliance is similar. Malagasy traders limit their exposure to potential breach of contract by adopting commercial practices that leave little room for abuse. Most transactions take a simple cash-and-carry form. Supplier credit is infrequent, and the placement of orders is uncommon. Payment by check and invoicing are virtually unheard of. Traders personally inspect the quality of goods purchased in nearly all transactions. Econometric analysis indicates that exposure is the dominant risk factor in all cases of contractual breach.

Survey results further show that recourse to legal institutions is rare, but that it increases with the severity of the dispute. The use of police and courts is indeed highest 
in theft cases and lowest in late delivery and deficient quality cases, with non-payment by clients in between. Direct negotiation with the other party is the dominant conflict resolution method in contractual disputes. Traders' propensity to solve disputes and to resume trade with each other is shown to depend critically on the use of direct negotiations with the other party. Recourse to negotiations in turn depends on the strength of the relationship between trading partners. These results are broadly similar to those reported by Bigsten et al. (1998) for African manufacturing. They confirm Fafchamps and Minten's (1998a) earlier conclusion that relationships play an important role in the resolution of contractual disputes among Malagasy traders.

Finding that legal institutions do not play an important role in the enforcement of contracts begs the question of which alternative mechanism is used by Malagasy traders. Our analysis suggest that trust-based relationships are the dominant contract enforcement mechanism among grain traders. Trust is established primarily through repeated interaction with little role for referral by other traders. Information on bad clients does not circulate widely, hence severely limiting group punishments for non payment. The lack of information sharing does not result from the existence of linguistic, ethnic, or religious obstacles to communication. Rather, it may be due to the disruption of pre-existing Asian networks following food riots in the late 1980's (e.g., Blanchy (1995)). Why native networks did not emerge in their stead remains a mystery, however.

To summarize, grain trade in Madagascar ressembles a flea market more than the sophisticated business world that proponents of market liberalization typically envision. Although the direct costs of theft and contractual breach appear low, the methods that surveyed traders use to minimize risk exposure can but add to transactions costs. The need for traders to personally inspect quality on each delivery, for instance, combined 
with their unwillingness to delegate quality control to subordinates and with their reluctance to hire additional workers for fear of theft, undoubtedly restrict firm size and firm growth. The need to guard stocks in person, the total absence of payment by check (that adds to the risk of theft), the infrequent use of trade credit, and the difficulty of placing orders complicate the conduct of business and make trade very labor and management intensive.

The transactions costs of trade are ultimately paid by producers and consumers in the form of a larger spread between farm-gate and retail price (e.g., IFPRI (1998)). The welfare cost of flea markets is thus not negligible. In addition, judging from the extreme dispersion in firm size (Gini coefficient of total sales around 0.75) and the fact that better connected traders economize on transactions costs and reap higher sales and profits (e.g., Fafchamps and Minten (1998a)), it is far from clear that competition yields efficiency. Indeed, Fafchamps and Minten's (1998b) finding that traders with better social network capital make more profits suggest that they do not take advantage of their lower costs to drive out small, unconnected traders. In other words, in a flea market economy, the coexistence of a large number of atomistic firms with a small number of large, well connected traders should not be taken as an indication that competitive forces are sufficient to eliminate rents (see Barrett (1997b) for a similar observation). This is because, among other things, small traders' efforts to protect their property rights and avoid being cheated leads to high transactions costs.

The rest of this paper is organized as follows. We begin in Section 1 with a brief description of the surveys. Section 2 follows with an analysis of the incidence of theft and breach of contract. Regression analysis is presented that tries to identify their determinants. Deterrence and contract enforcement mechanisms are discussed in Section 3. 
Conclusions are presented at the end.

\section{Section 1. The Data}

A survey of agricultural traders was conducted in Madagascar in a joint project between IFPRI (the International Food Policy Research Institute) and the local Ministry of Scientific Research (FOFIFA). The first round of the survey was held between May 1997 and August 1997 and collected information on the individual characteristics of traders and on the structure, conduct, and performance of the trading sector. A second survey round was conducted between September 1997 and November 1997; it focused on the nature of respondents' relationships with other traders, clients, and suppliers.

The sample design was constructed so as to be as representative as possible of all the traders involved in the whole food marketing chain from producer to consumer, wherever located. Three main agricultural regions were covered (Fianarantsoa, Majunga, and Antananarivo) and the sampling frame within these regions was set up so as to cover traders operating at three different levels:

(1) Traders operating in big and small urban markets in the main town of every province (faritany) and district (fivondronana). These traders are mostly wholesalers, semi-wholesalers, and retailers.

(2) Urban traders located outside the regular markets. These often are bigger traders, processors (e.g., rice millers), and wholesalers.

(3) Traders operating on rural markets at the level of the rural county (firaisana). These are mostly big and small assemblers and itinerant traders. Rural firaisanas were selected through stratified sampling based on agro-ecological characteristics so as to be representative of the various kind of marketed products and marketing seasons. 
The survey focused on traders that marketed locally consumed staples such as rice, cassava, potatoes, beans, and peanuts. The different forms in which these products are marketed were taken into consideration, i.e., paddy and milled rice, maize and maize flour, etc. Traders involved primarily in export crops, fruits, vegetables, and minor crops were excluded. Most surveyed traders -- 67\% -- report rice as the agricultural product they trade most intensively. This reflects the importance of rice as the main staple food in the country. Other most actively traded products are beans and lentils (18\% of the sample report them as their main traded product), cassava (5\%), potatoes (5\%), peanuts $(4 \%)$, and maize (2\%).

A total number of 850 traders were surveyed in the first round, 739 of whom were surveyed again in the second round. The analysis presented here is based on traders that could be located in the two rounds. ${ }^{2}$ The main characteristics of respondents are summarized in Table 1. Total sales measures output. Value added, defined as the difference between the value of total sales and total purchases, represents total returns to labor, management, and capital. As suggested by the presence of large standard deviations, these averages hide extreme variation in traders' size of operation: the coefficients of variation of sales and value added are 2.6 and 3.7, respectively. The corresponding Gini coefficients are 0.761 and 0.702 . Expressed in percentage of annual sales, the average trade margin is $15 \%$. Assuming that grain changes hands four times between producer and final consumer, such margins translate into a consumer price on average $75 \%$ higher than the farm-gate price (e.g., IFPRI (1998)). Margins of this magnitude are common in

\footnotetext{
2 The category of traders which were hardest to trace during the second survey round are those who are least formal and have the least permanent form of operation. As a result, small itinerant traders tend to be underrepresented in the results reported here.
} 


\section{Sub-Saharan Africa.}

Detailed information is available on working capital and equipment (mostly weighting equipment), storage capacity and vehicles, telephone usage, labor, management, human capital, and social capital. The data show that the surveyed businesses are fairly unsophisticated by western standards: average working capital is roughly equivalent to 2,000 US dollars -- a large number compared to the annual GDP of Madagascar which was 230 US dollars in 1997, but very small compared to the turnover of grain trading companies in the U.S. or Europe. The great majority of surveyed traders do not have their own transportation equipment, nor do they use telephones very often. Each trading business has an average of four workers, including the owner/manager. Most respondents work full time in trade and remain traders all year round. On average, they are fairly well educated by Madagascar standards. In Madagascar trade is conducted in Malagasy, the national language which is spoken throughout the island. French is commonly used in the administration and in some (primarily urban) secondary schools. Close to half of the respondents commonly speak a language other than Malagasy -- mostly French. Information was also collected on various dimensions of the respondents' social network: the number of close relatives in agricultural trade; the number of (non-family) traders that respondents know; the number of friends and family members who can help the business stay afloat in times of trouble; and the number of suppliers and clients that respondents know personally. Fafchamps and Minten (1998b) examine how these different forms social network capital affect firm performance.

Data are also available on the way traders deal with each other. On average, surveyed traders buy and sell mostly in cash. Invoicing and the use of checks are virtually unheard of. A small but non-negligible proportion of traders nevertheless manage to 
receive and grant trade credit -- $15.8 \%$ and $13.6 \%$ of total grain purchases and sales, respectively -- typically for one week. Since respondents rotate their working capital several times per month, even short term credit can significantly add to their buying capacity. Surveyed traders do part of their business with regular suppliers and clients, with whom they are more likely to place orders and receive or grant credit and less likely to inspect quality. This conforms with theoretical expectations according to which relationships facilitate contract enforcement (e.g., Ghosh and Ray (1996), Kranton (1996), Fafchamps (1998a)).

\section{Section 2. Incidence of Theft and Breach of Contract}

Table 2 summarizes the incidence of theft and breach of contract in the twelve months preceding the survey. Only a small proportion of traders were victim of theft and the total value of stolen goods accounted for less that $0.3 \%$ of total annual sales. Incidence appeared much higher for a handful of respondents, but we cannot rule out the possibility of error in data collection. Of 57 instances of recent thefts, 24 took place at the trader's store during the day, 24 took place at night, 7 during transport, and 3 while the goods were in the hands of third parties (Table 3). Not all thefts are equally costly, however: the average value of stolen goods is on average nine times higher for thefts at night or during transport. In a third of theft cases, respondents were confident that employees were not responsible; in the rest of the cases, respondents either suspected employees or were unsure. Not surprisingly, traders who suspect employees are those with more employees -- 7.7 vs. 3.4 among those respondents who do not suspect their workforce. Pilferage by employees is thus is a concern of surveyed traders, especially large ones. 
Breaches of contract are somewhat more prevalent, but they too affect only a minority of survey respondents (Table 2). The proportions of sales and purchases affected by breach of contract are all less than $5 \%$ on average, although they are much higher for some traders. Deficient quality and late payment are the most often cited problems, affecting a fifth and a third of traders, respectively. But their implied cost is only a fraction of the value of the transaction -- e.g., the loss in value due to inferior quality and the opportunity cost of capital in case of late payment. The same is true for late delivery. Non payment, a much more severe form of breach of contract, is quite rare and affects only $0.04 \%$ of all transactions. These findings are similar to those reported by Fafchamps (1996), Bigsten et al. (1998).

Judging from these numbers, the direct costs of theft and breach of contract are quite small -- less than one percent of annual sales on average. ${ }^{3}$ Some traders occasionally suffer more severe losses, however, especially when goods are stolen at night or during transport. On the basis of these numbers, one may be tempted to conclude that the rule of law prevails in Madagascar and that malfeasance is adequately deterred by existing legal institutions. A closer inspection of the evidence demonstrates, however, that such a conclusion is unwarranted: the low incidence of malfeasance owes more to prevention by traders than to legal deterrence. Surveyed traders indeed go to great lengths to minimize the risk of theft and breach of contract. Table 3 lists some of the measures surveyed traders take to minimize theft. Over a third of respondents declare refraining from hiring additional workers for fear of employee theft. The magnitude of

3 Estimated from Table 2 assuming that losses from late delivery and late payment account for at most $10 \%$ of the value of sales and that losses from deficient quality account for at most $5 \%$ of sales value. With these generous assumptions, total losses amount to $0.89 \%$ of total sales -- $0.28 \%$ from theft, $0.04 \%$ from non-payment, $0.16 \%$ from late delivery, $0.22 \%$ from deficient quality, and $0.19 \%$ from late payment. Recovered goods are not subtracted from loss from theft. 
this figure -- and its likely welfare cost in an economy where underemployment is rampant and trade is a major source of employment -- perfectly illustrates the idea that the indirect costs of malfeasance are potentially much larger than its direct costs (see Hart (1988) for a similar observation). Table 3 also shows that, among traders who stock agricultural products at night, two third sleep on the premices. Virtually all overnight storage is both locked and guarded. Of those traders who transport goods from one town to another, $43 \%$ either pay for protection or travel in convoy. ${ }^{4}$ In addition, thirteen traders -- all from the same province (Fianaranatsoa) -- declare avoiding certain routes for fear of highway robbery.

A similar picture emerges for quality control. Table 4 indicates that prices vary with product quality. For instance, the price differential between the two most traded rice qualities oscilate between $8 \%$ and $9 \%$ in the capital city. Some of this quality variation is due to differences in traditional crop varieties across regions. ${ }^{5}$ This source of quality variation can presumably be controled by traders simply by verifying the geographical origin of the goods they buy. Some of the variation in quality, however, does not come from regional differences but from improper handling ${ }^{6}$ and from natural variation in traditional seed material, thereby making it harder to ascertain. Taken together, the evidence indicates that price varies with quality and that quality cannot be perfectly inferred by a product's region of origin. As table 4 shows, the overwhelming majority of surveyed traders and their clients respond to quality risk by inspecting each and every purchase.

\footnotetext{
4 Interestingly, only two traders report doing both.

5 Unlike in advanced economies where most food is produced from a handful of highly homogeneous improved seeds, farmers in Madagascar as well as in much of the tropics rely on their own output for seeds. This process results in widespread dispersion in genetic traits and output characteristics across regions and even villages.

6 E.g., high moisture content, fungus and pest damage, brokens, presence of stones and sand.
} 
The importance of quality inspection is further underscored by the fact that the task is virtually never delegated to family helpers, employees, or collecting agents. Although we did not attempt to measure the time actually spent on quality verification by Malagasy traders, casual observation suggests that the process can be very time consuming. Furthermore it requires that the trader be present at each purchase, thereby complicating the conduct of business and requiring extensive travel on the part of the trader himself or herself.

A similar pattern is observed with respect to other sources of breach of contract: $85 \%$ of surveyed traders never place orders from suppliers; and 54\% never give credit to customers. In addition, payment by check is unheard of; all transactions are strictly cash. ${ }^{7}$ they complicate transactions and the planning of business.

However costly, these efforts are in general effective in minimizing the incidence of malfeasance. As indicated by Table 5, simple $t$ tests indicate that not storing overnight all but eliminates the risk of theft. Not placing orders cancels the risk of late delivery, and not giving credit to clients dramatically reduce the risks of late and non payment. The results reported in Table 5 may, however, be unreliable because they ignore the effect of other possible determinants of malfeasance, such as regional differences in incidence, and the likely endogeneity of prevention.

We therefore complement the bivariate analysis reported in Table 5 with a multivariate regression analysis that controls for possible endogeneity. Results regarding theft are presented in Table $6 .{ }^{8}$ The dependent variable is the value of annual losses due

7 The use of check is absent even of credit transactions, presumably because Malagasy banks are notoriously slow in processing payments and transfers. At the time of the survey, it alledgedly took two to three weeks for banks to transfer funds from agencies of the same bank located in two different towns.

8 To control for the possibility that results are driven by outliers (see large 'Maximum' frequencies in Table 2), all regressions on determinants of theft and breach of contract were reestimated after dropping all 
to theft as a proportion of annual sales. The first column examines the determinants of theft incidence without conditioning on risky behavior. Explanatory variables include total sales (to control for size), human capital (measured by years of schooling and the $\log$ of years of trade experience), and location dummies. Presumably, larger firms may experience more theft because they process a larger volume of goods and find it harder to control their employees. Total sales are instrumented to control for the possible feedback effect that theft may have on sales. ${ }^{9}$ Human capital is included to control for the possibility that smarter, more experienced traders might be better able to prevent theft. Location variables control for general crime environment and other spatial effects. Insecurity is generally perceived to be highest in the Majunga plaines region and fairly high in the Majunga plateaux region. We would therefore expect theft to be more problematic in these regions. Results show that firms that sell more face more theft. Other variables are not significant.

We then introduce risk factors such as overnight storage and storage capacity as additional regressors (second column of Table 6). As expected, results show that traders who store overnight are more at risk. The magnitude of the coefficient is very large. Storage capacity has the expected sign but its $t$ value is below standard levels of significance. As anticipated, the risk of theft is much larger in the two Majunga regions, and largest in the region where insecurity is generally perceived to be highest. Experimentation with other regressors suggests that transporting raises theft incidence and that sleeping in one's store reduces it, but the effects are no longer significant once location frequencies larger than 10\%. Qualitative results are unchanged, but estimated parameter are in general smaller in magnitude.

9 The instrumenting equation is presented in appendix A. Instruments include various measures of physical and working capital, labor and management, social network capital, enterpreneurial traits and family background, and aggregate shocks. See Fafchamps and Minten (1998b) for more details. 
dummies are included in the regression. ${ }^{10}$ To control for possible endogeneity, we then instrument risky behavior variables and replace them by their predicted value. ${ }^{11}$ Results are presented in the third column of Table 6 . They confirm that risky behavior raises the incidence of theft. The effect of regional dummies is unchanged.

We run similar regressions for various forms of breach of contract. To control for network capital effects, we include as additional regressors the (log of the) number of close relatives in agricultural trade and the number of suppliers and clients known personally by the respondent. Fafchamps and Minten (1998b) indeed demonstrate that better connected traders not only make more profits but also are more likely to place orders and to give and receive trade credit. Following much of the literature (e.g., Fukuyama (1995), Kranton (1996), Greif (1993), North (1990)), they hypothesize that social connections mitigate opportunism. Regional dummies are included to capture possible differences in road infrastructure, climate, and other location specific factors. Road quality is best in and around the capital city, and in Majunga plaines; it is by far the worst in Majunga plateaux and also fairly low in Fianaranatsoa. To the extent that late delivery is due to problems during transport, we would therefore expect late delivery to more prevalent in these regions. Rainfall is most abundant in the Fianaranatsoa cotes et falaises region and in Vakinantaratra; it is lowest in Majunga. Since deficient quality is often related to imperfect drying, we would expect quality to be more problematic in humid regions.

Regression results are presented in Tables 7 to 10. Except for the verification of quality, which has the right sign but is not statistically significant, ${ }^{12}$ the coefficients of all

\footnotetext{
10 The fact that robust results are difficult to obtain with more regressors is not altogether surprising given that there are only 57 non-zero observations.

11 Instrumenting equations are presented in Appendix B. Instruments include personal wealth, age, and sex of the owner, social network capital, personal traits, and family background.

12 Quality verification is significant when location dummies are omitted.
} 
risk factors have the right sign and are significant. Contrary to expectations, traders with family members in agricultural trade appear to face a higher incidence of contractual breach. For deficient quality and for non-payment, the effect is significant even after we control for risky behavior. This suggests that having more relatives in trade favors contractual opportunism, presumably because traders find it difficult to discipline relatives who operate as suppliers or clients. This may explain why Fafchamps and Minten (1998b) find that respondents with more relatives in agricultural trade get significantly lower profits after controling for all factors and inputs.

Results also indicate the presence of very strong regional differences in the incidence of breach of contract, even after we control for urbanization level. Contrary to expectations, however, we do not find that regions with inferior road infrastructure have more late delivery problems and that wetter regions have more deficient quality cases. If anything, Majunga plateaux, the region with by far the poorest road infrastructure, has less late delivery cases than other regions, and the Fianaranatsoa cotes et falaises region, which is the most humid, has fewer cases of deficient quality. Results indicate that Antananarivo and the region surrounding it (the omitted region dummy) have more late delivery problems. This possibly reflects the fact that the capital city is a major food deficit area where the urgency of the market is felt more strongly than elsewhere.

Contrary to expectations, econometric results do not suggest that quality problems are more frequent in the most humid area, the Fianaranatsoa cotes et falaises region. If anything, quality deficiencies are highest in the Vakinankaratra and Antananarivo regions (the omitted region dummy), two areas of moderate to high rainfall. In terms of payment by clients, the incidence of breach of contract appears to be significantly higher in the rural areas surrounding the capital city. The reason for these regional differences 
is unclear. ${ }^{13}$ One possibility is that they correspond to different equilibria of a flexible contract enforcement game. This issue deserves more research.

To summarize, we have shown that the incidence of theft and contractual breach is low but also that Malagasy grain traders go to great length to reduce their exposure to malfeasance. Regression analysis demonstrated that prevention is effective in the sense that traders who opt for more risky trading practices face a higher incidence of malfeasance. The question now remains of why prevention is the dominant method grain traders use to reduce risk. To answer this question, we now examine what happens when a theft or a breach of contract actually occur.

\section{Section 3. Legal Institutions and Deterrence}

Recourse to the police is relatively frequent in cases of theft: as shown in Table 11, one third of theft cases were reported to the police, and respondents went to court -presumably as witnesses -- in ten percent of the theft cases. Calling upon the police had no noticeable effect on the probability to recover stolen item, however: of those traders who went to the police, $24 \%$ retrieved all or part of the stolen goods; of those who did not, $34 \%$ retrieved something. The difference is not statistically significant $(\mathrm{t}$ value of 0.81). The small number of observations (57 cases of theft) precludes further analysis.

We have a little more information on contractual disputes with suppliers and clients. Surveyed traders were asked whether they ever called upon an intermediary to mediate their contractual disputes with suppliers or clients, and whether they ever went to the police, a lawyer, or a court in relation with a purchase or sales dispute. Their responses,

\footnotetext{
13 Differences in the function (e.g., collector, wholesaler, retailer, or microretailer) exercised by the respondent or in the crops they sell, do not, for instance, account for these regional differences.
} 
listed in Table 11, show that, apart from an occasional recourse to the police, the use of legal institutions by Malagasy grain traders is extremely low in contractual disputes with suppliers and clients.

One conceivable interpretation of these numbers is that legal enforcement in Madagascar is so effective and predictable that parties rationally anticipate the outcome and prefer to settle beforehand to avoid litigation costs. Table 11 indeed indicates that direct negotiations are the instrument of choice to resolve contractual disputes. Mediators are used occasionally as well. But the data also show that the threat of recourse to the police or to courts is extremely rare. In addition, these threats tend to be used only in desperate circumstances. Of the eight cases in which a threat of police action was mentioned, for instance, five were relative to non-payment by a client. Finally, surveyed traders hardly ever seek the advice of a lawyer. Taken together, these observations suggest that the threat of court action is not an important deterrent of contractual opportunism in the Malagasy grain market. Yet, lack of familiarity with courts and legal institutions does not seem to be the main reason for lack of usage: the fact that one third of robbed traders went to the police and $11 \%$ went to court do not suggest reluctance for legal institutions per se. What the data therefore indicates is that contractual obligations are largely seen as outside the purview of the law -- with the possible exception of nonpayment.

This interpretation begs the question of what is the alternative contract enforcement mechanism: if legal institutions offer little or not protection against opportunistic breach, why do surveyed traders bother to place orders and grant credit at all? One thing that is quite clear from interviews is that violence is not seen as a common or even correct way of resolving contractual disputes. If anything, recourse to courts and police is low 
because traders perceive these institutions to be too antagonistic and conflictual. Reference to 'trust' is the most common answer when traders are asked why contracts are honored. To understand what 'trust' means to Malagasy traders, we investigate what happens in dispute cases. The first striking finding is that most contractual disputes are resolved (85\% of supplier cases and $79 \%$ of client cases) and trade is resumed in most cases (91\% of supplier cases and $78 \%$ of client cases). In addition, dispute resolution and resumption of trade are highly correlated; $79 \%$ of disputes with suppliers and $73 \%$ of disputes with clients are resolved and trade resumed. Similar findings are reported for African manufacturers in Fafchamps (1996) and Bigsten et al. (1998).

This suggests that breach of contract, although unwelcome and costly for respondents, occurs within the context of long term relationships. A reasonable interpretation, largely confirmed by informal discussions with respondents and casual observation, is that parties implicitly agree to continue trading with each other as long as contractual breach remains infrequent and provided that, when it occurs, a good faith effort is made to resolve the situation. If these conditions are satisfied, the relationship continues; otherwise it is severed. In other words, relational contracting as modeled for instance by Ghosh and Ray (1996) and Fafchamps (1998a) is the key contract enforcement mechanism.

This interpretation is confirmed by regression analysis. Table 12 for instance shows that more personalized relations and longer acquaintance with suppliers and clients is associated with efforts to resolve contractual disputes through direct negotiation and, in the case of clients, through mediators. A contrario, regression results also indicate that respondents with relatives in agricultural trade are much less likely to negotiate payment problems with clients. Although a priori surprising, this finding is consistent with the idea 
that disciplining relatives is difficult: if so, why bother waste time negotiating with them. Table 13 and 14 further illustrate that direct negotiations have a strong positive effect on the probability of resolving the dispute and resuming trade. In other words, good faith efforts to iron out difficulties are essential to the preservation of trust and relationships. Results again show that payment problems are less likely to be resolved for respondents who have relatives in agricultural trade -- and who presumably buy and sell from them.

The reader may want to know whether relational contracting as enforcement mechanism is complemented by information sharing on cheaters and by collusion to exclude them from future trade, as suggested for instance by Kandori (1992), Greif (1993), and others. Table 15 provides some useful information in this respect. We see that, of those traders who obtain supplier credit, less than one fifth come recommended by other traders. The dominant credit screening procedure is to purchase several times from the same trader, thereby establishing mutual trust. The most common action taken in response to non payment is to stop deliveries. Similar findings are reported by Fafchamps (1996) for Ghana. Very few respondents expect to involve the police or the courts in debt collection, hence confirming that the trade relationship constitutes its own collateral. There is some information sharing about clients who do not pay but its reach is limited: a majority of respondents estimate that a client who does not pay is unlikely or very unlikely to lose credit from other suppliers. Exclusion from future trade credit is thus not the dominant form of contract enforcement, although it plays a secondary role.

These findings are further confirmed by Table 16. Clients themselves are the main source of information on which suppliers rely before granting credit. For two third of the respondents, this is the only source of information on which they rely for screening trade credit applicants. Only a quarter of the respondents obtain information from other 
traders; $14 \%$ obtain information from other sources. There appears to be no systematic effort to share information on clients who do not pay: only $13 \%$ of credit givers discuss bad clients with other traders once of month or more; one quarter never discuss bad clients at all.

Why there is not more information sharing is unclear. One may be tempted to assume that the ethnic origin of traders is too heterogeneous to allow a fluid exchange of information (e.g., Cornell and Welch (1996), La Ferrara (1997)). This is not borne out by the data, however. First, all surveyed traders -- like all inhabitant of Madagascar -- speak a single common language. Second, traders operate predominantly in their region of origin: over $85 \%$ of traders operate in the district (Fivondronana) of their birth, and the coefficient of correlation between the postal code of their place of birth and the location of their trading activity is as high as 0.76 . Only 9 traders in the sample are of foreign origin -- mostly from Asia. Finally, the overwhelming majority of respondents -- 91\% -share a common religion. The idea that linguistic, ethnic, or religious barriers prevent the circulation of information cannot, therefore, be sustained.

One item of information that is worth pointing out is that riots against traders took place in the late 1980's. According to Lonely Planet (1994), "Indo-Pakistani traders [] bore the brunt of Malagasy violence in the 1987 riots. [T] he Indian premises on either sides [of the main street in Tulear] along with most of the central area were gutted" (p.220). Blanchy (1995) reports that in five major cities, Asian owned shops were looted and burned; many Asians feared for their life and fled the country, if only temporarilly. Barrett (1997b) reports that Asian traders refused to be interviewed by Malagasy enumerators and writes that "[it] is difficult to overstate the sensitivity of ethnic Asian food marketing intermediaries to the political risks of their trade". Judging from 
Blanchy's (1995) account of Asian businesses in Madagascar, ethnic Asian business networks prior to the riots ressembled their counterparts in Kenya (e.g., Himbara (1994), Marris (1971), Fafchamps (1998b), Fafchamps et al. (1994)). If, as it is likely, Asian traders have pulled out of grain markets to reduce their exposure to political risk, the resulting disruption in existing business networks could explain the current lack of sophistication of grain trade in the country. Still, this does not explain why indigenous networks of information sharing have not formed to replace Asian networks them. These issues deserve more research.

\section{Conclusions}

This paper has studied liberalized grain markets in Madagascar and examines how property rights are protected and contracts are enforced among agricultural traders. We found that the incidence of theft and breach of contract is low and that the losses resulting from such instances are small. This, however, does not result from reliance on legal institutions -- actual recourse to police and courts is fairly rare, except in cases of theft -but from traders' reluctance to expose themselves to opportunism. Judging from the evidence collected, the indirect costs of malfeasance prevention are likely to be much higher than the direct costs of theft and breach of contract. As a result, Malagasy grain trade resembles a flea market, with little or no forward contracting and high transactions costs.

We also investigated how contracts are enforced. We found that the dominant contract enforcement mechanism is trust-based relationships. Trust is established primarily through repeated interaction with little role for referral by other traders. Information on bad clients does not circulate widely, hence severely limiting group punishments for non 
payment. As far as we are able to judge, the lack of information sharing does not result from the existence of linguistic, ethnic, or religious obstacles to communication. In spite of great diversity in external appearance, Malagasy society is surprisingly homogeneous. Rather, the culprit might be sought in the disruption of pre-existing Asian networks that followed food riots in the late 1980's. More research is needed to assess why native networks did not emerge in their stead and what institutional changes can improve Malagasy grain markets. 


\section{References}

Baer, H. L. and Gray, C. W., Debt as a Control Device in Transitional Economies: The Experiences of Hungary and Poland, The World Bank, Washington, D.C., June 1995. Policy Research Working Paper No. 1480.

Barrett, C. B., 'Liberalization and Food Price Distributions: ARCH-M Evidence from Madagascar,' Food Policy, 22(2): 155-173, 1997a.

Barrett, C. B., "Food Marketing Liberalization and Trader Entry: Evidence from Madagascar,' World Development, 25(5): 763-777, May 1997b.

Benson, B. L., The Enterprise of Law, Pacific Research Institute for Public Policy, San Francisco, 1990.

Berg, E., “The Liberalization of Rice Marketing in Madagascar,' World Development, 17, no.5: 719-728, 1989.

Bigsten, A., Collier, P., Dercon, S., Fafchamps, M., Gauthier, B., Gunning, J. W., Isaksson, A., Oduro, A., Oostendorp, R., Patillo, C., Soderbom, M., Teal, F., and Zeufack, A., Contract Flexibility and Conflict Resolution: Evidence from African Manufacturing, Department of Economics, Stanford University, Stanford, March 1998. (mimeograph).

Blanchy, S., Karana and Banians: Les Communautés Commercantes d'Origine Indienne à Madagascar, L'Harmattan, Paris, 1995.

Cornell, B. and Welch, I., "Culture, Information and Screening Discrimination,', J. Polit. Econ., 104(3): 542-571, 1996.

Dorosh, P. and Bernier, R., "Staggered Reforms and Limited Success: Structural Adjustment in Madagascar,' Adjusting to Policy Failure in African Economies, p. 332-365, David Sahn (ed.), Food Systems and Agrarian Change Series, Cornell University Press, Ithaca and London, 1994.

Ensminger, J., Making a Market: The Institutional Transformation of an African Society, Cambridge University Press, New York, 1992.

Fafchamps, M., Biggs, T., Conning, J., and Srivastava, P., Enterprise Finance in Kenya, Regional Program on Enterprise Development, Africa Region, The World Bank, Washington, D.C., June 1994.

Fafchamps, M., "The Enforcement of Commercial Contracts in Ghana," World Development, 24(3): 427-448, March 1996.

Fafchamps, M., Market Emergence, Trust and Reputation, Stanford University, Stanford, February 1998a. (mimeograph).

Fafchamps, M., Ethnicity and Credit in African Manufacturing, Stanford University, Stanford, November 1998b. (mimeograph).

Fafchamps, M. and Minten, B., Relationships and Traders in Madagascar, Department of Economics, Stanford University, Stanford, June 1998a. (mimeograph). 
Fafchamps, M. and Minten, B., Returns to Social Capital Among Agricultural Traders: Evidence from Madagascar, Department of Economics, Stanford University, Stanford, June 1998b. (mimeograph).

Fukuyama, F., Trust: The Social Virtues and the Creation of Prosperity, The Free Press Paperbacks, New York, 1995.

Ghosh, P. and Ray, D., "Cooperation in Community Interaction Without Information Flows,', Review of Economic Studies, 63: 491-519, 1996.

Greif, A., "Contract Enforceability and Economic Institutions in Early Trade: The Maghribi Traders' Coalition,' Amer. Econ. Rev., 83(3): 525-548, June 1993.

Greif, A., "Cultural Beliefs and the Organization of Society: A Historical and Theoretical Reflection on Collectivist and Individualist Societies,' J. Polit. Econ., 102(5): 912-950, 1994.

Hart, K., "Kinship, Contract, and Trust: the Economic Organization of Migrants in an African City Slum,' Trust: Making and Breaking Cooperative Relations, D. Gambetta (ed.), Basil Blackwell, New York, 1988.

Hendley, K., Murrell, P., and Ryterman, R., Law, Relationships, and Private Enforcement: Transactional Strategies of Russian Enterprises, IRIS, University of Maryland, College Park, September 1998. (mimeograph).

Himbara, D., "The Failed Africanization of Commerce and Industry in Kenya,' World Development, 22(3): 469-482, 1994.

IFPRI, Une Analyse Descriptive du Marché des Intrants et des Produits Agricoles et du Comportement des Ménages Ruraux à Madagascar, Ministère de la Recherche Scientifique de Madagascar et International Food Policy Research Institute, Washington D.C., April 1998. Special Report Number Two, Submitted to USAID/Madagascar.

Kandori, M., "Social Norms and Community Enforcement," Review Econ. Stud., 59: 63-80, 1992.

Kranton, R. E., "The Formation of Cooperative Relationships,' Journal of Law, Economics, and Organizations, 12(1): 214-233, 1996.

La Ferrara, E., Ethnicity and Reciprocity: An Analysis of Credit Transactions in Ghana, Department of Economics, Harvard University, Cambridge, Mass., May 1997. (mimeograph).

Lonely Planet, Madagascar and Comoros, Lonely Planet Puliblications, New York, 1994.

Marris, P., "African Businessmen In a Dual Economy,' Journal of Industrial Economics, 19: 231-245, 1971.

McMillan, J., "Markets in Transition,' Advances in Economics and Econometrics: Theory and Applications, David M. Kreps and Kenneth Wallis, Eds, Cambridge University Press, Cambridge, 1996. 
Milgrom, P. R., North, D. C., and Weingast, B., "The Role of Institutions in the Revival of Trade: The Law Merchant, Private Judges, and the Champagne Fairs," Economics and Politics, 2(19): 1-23, 1991.

North, D. C., The Rise of the Western World, Cambridge U.P., Cambridge , 1973.

North, D. C., Institutions, Institutional Change, and Economic Performance, Cambridge University Press, Cambridge, 1990.

Root, H., Environment for Investment in Madagascar: Institutional Reform for Market Economy, Center for Institutional Reform and the Informal Sector, University of Maryland at College Park, College Park, MD, 1993. 
Table 1. Characteristics of Surveyed Traders

\begin{tabular}{|c|c|c|c|}
\hline A. Dependent variables & Unit & Mean & Std. dev. \\
\hline Total annual sales of agricultural food products & US \$ (1) & 39337 & 102087 \\
\hline Total annual value added & US $\$(1)$ & 5862 & 21731 \\
\hline \multicolumn{4}{|l|}{ B. Capital and equipment } \\
\hline Working capital & US $\$(1)$ & 2061 & 7635 \\
\hline Dummy if subsidiary & Yes $=1$ & $4.7 \%$ & \\
\hline Value of equipment & US \$ (1) & 399 & 2088 \\
\hline Storage capacity & Metric tons & 26 & 134 \\
\hline Number of vehicles & Number & 0.14 & 0.50 \\
\hline Utilization of telephone & Yes $=1$ & $16.2 \%$ & \\
\hline \multicolumn{4}{|l|}{ C. Labor and management } \\
\hline Manpower (in months/year) & Month/year & 39.5 & 131.8 \\
\hline Dummy if full time trader & Yes $=1$ & $87.3 \%$ & \\
\hline Dummy if trader all year round & Yes $=1$ & $83.4 \%$ & \\
\hline Years of schooling of owner/manager & Years & 9.1 & 3.5 \\
\hline Years of experience in agricultural trade & Years & 6.0 & 4.5 \\
\hline Commonly speaks a language other than national language & Yes $=1$ & $42.8 \%$ & \\
\hline Gender of trader & Female $=1$ & $45.7 \%$ & \\
\hline \multicolumn{4}{|l|}{ D. Social capital } \\
\hline Number of relatives in agric. trade & Number & 0.7 & 1.2 \\
\hline Number of traders known & Number & 8.8 & 9.1 \\
\hline Number of people who can help & Number & 2.3 & 1.7 \\
\hline Number of suppliers known personally & Number & 4.6 & 7.6 \\
\hline Number of clients known personally & Number & 8.6 & 14.2 \\
\hline \multicolumn{4}{|l|}{ E. Location } \\
\hline In capital city & Yes $=1$ & $15.7 \%$ & \\
\hline In another city & Yes $=1$ & $31.3 \%$ & \\
\hline In Vakinankaratra region & Yes $=1$ & $19.9 \%$ & \\
\hline In Fianar/hauts plateaux region & Yes $=1$ & $24.9 \%$ & \\
\hline In Fianar/cotes et falaise region & Yes $=1$ & $11.5 \%$ & \\
\hline In Majunga/plaines region & Yes $=1$ & $12.2 \%$ & \\
\hline In Majunga/plateaux region & Yes $=1$ & $13.4 \%$ & \\
\hline
\end{tabular}

(1) Computed using an exchange rate of 5000 Francs Malgaches for 1 US\$. 
Table 2. Incidence of Theft and Breach of Contract

1. Theft

Traders who experienced theft in last 12 months

Value of stolen goods relative to annual sales

2. Late delivery by suppliers

Traders who experienced late delivery in last 12 months

Proportion of late deliveries in total transactions

3. Deficient quality of deliveries by suppliers

Traders who experienced deficient quality in last 12 months

Proportion of deficient quality deliveries in total transactions

4. Late payment by clients

Traders who experienced late payment in last 12 months

Proportion of late payments in total transactions

5. Non-payment by clients

Traders who experienced non payment in last 12 months

Proportion of non payments in total transactions $\begin{array}{rrr}\text { Mean } & \text { Min. } & \text { Max. } \\ 7.70 \% & & \\ 0.28 \% & 0.0 \% & 93.0 \%\end{array}$

$8.81 \%$

$1.56 \% \quad 0.0 \% \quad 100.0 \%$

$20.60 \%$

$4.44 \% \quad 0.0 \% \quad 100.0 \%$

$30.80 \%$

$1.91 \% \quad 0.0 \% \quad 100.0 \%$

$6.82 \%$

$0.04 \% \quad 0.0 \% \quad 4.2 \%$

Note: the exact number of valid observations varies somewhat from question to question (from 728 to 738 ). 


\section{Table 3. Exposure to Theft and Prevention}

Traders who experienced a theft in last 12 months $\quad 8 \%$ Of those who experienced a theft:

$\%$ who experienced theft at store during the day $42 \%$

$\%$ who experienced theft from storage at night $\quad 40 \%$

$\%$ who experienced theft during transport/consignment $18 \%$

Of those who experienced a theft:

$\%$ who think theft was not due to employee $32 \%$

$\%$ who suspect an employee $37 \%$

$\%$ who do not know $26 \%$

Traders who refrain from hiring workers for fear of theft $37 \%$

Traders who leave stocks overnight at sales location $\quad 72 \%$

Of those who stock overnight:

$\%$ with lock on storage location $\quad 99 \%$

$\%$ who sleep on premices $\quad 64 \%$

$\%$ who hire a guard $\quad 52 \%$

$\%$ who either sleep on premices or hire a guard $\quad 95 \%$

Traders who transport goods from one town to another $\quad 41 \%$

Of those who transport:

$\%$ who avoid certain locations for fear of theft during transpor $\quad 4 \%$

$\%$ who pay someone for protecting goods in transport $14 \%$

$\%$ who travel in convoy $30 \%$

$\%$ who either pay for protection or travel in convoy $43 \%$ 
Table 4. Variation of Quality and Inspection by Trader

Traders' assessment of quality variation

1. Whether prices vary with product quality

A lot

$33 \%$

A little bit

$61 \%$

Not at all

$7 \%$

2. Whether product quality varies by region of origin:

A lot

$37 \%$

A little bit

$57 \%$

Not at all

$6 \%$

3. Whether product quality varies within region of origin:

Always

Often

$5 \%$

Often

$14 \%$

Sometimes

$37 \%$

Seldom

$36 \%$

Never

$7 \%$

Average price differential between $\mathrm{C} 1$ and $\mathrm{C} 2$ quality rice (a):

Retail price

$9 \%$

Wholesale price

$8 \%$

Verification of quality before purchase:

1. Trader verifies quality:

Always

$84 \%$

Often

$13 \%$

Sometimes

$2 \%$

Never

$1 \%$

2. The person who verifies quality is:

Trader himself/herself

$93 \%$

Family helper

$4 \%$

Employee or collecting agent

$2 \%$

Nobody

$1 \%$

3. Client verifies quality:

Always

$85 \%$

Often

$11 \%$

Sometimes

$2 \%$

Never

$2 \%$

(a) Source: National Statistical Bureau, computed from dayly price figures fo Antananarivo, 1997. 
Table 5. Exposure and Incidence

\section{Theft and storage}

Trader leaves stocks overnight on sales location

Value of stolen goods relative to annual sales

Number of observations

2. Theft and transport

Trader transports goods from one location to another

Value of stolen goods relative to annual sales

Number of observations

3. Late delivery by suppliers

Trader places orders with suppliers

Proportion of transactions with late delivery

Number of observations

4. Deficient quality of deliveries by suppliers

Trader always inspects quality of supplies

Proportion of transactions with deficient quality

Number of observations

5. Late payment by clients

Trader grants credit to at least some clients

Proportion of transactions with late payment

Number of observations

6. Non-payment by clients

Trader grants credit to at least some clients

Proportion of transactions with non-payment

Number of observations

$\begin{array}{rrrr}\text { Yes } & \text { No } & t \text {-stat. } & p \text {-value } \\ 0.38 \% & 0.00 \% & -1.9016 & 0.0578 \\ 526 & 198 & & \\ & & & \\ \text { Yes } & N o & t \text {-stat. } & p \text {-value } \\ 0.28 \% & 0.28 \% & -0.0268 & 0.9786 \\ 307 & 423 & & \\ & & & \\ \text { Yes } & N o & t \text {-stat. } & p \text {-value } \\ 10.55 \% & 0.00 \% & -5.8100 & 0.0000 \\ 108 & 620 & & \\ & & & \\ \text { Yes } & N o & t \text {-stat. } & p \text {-value } \\ 4.19 \% & 5.76 \% & 0.9070 & 0.3660 \\ 616 & 112 & & \\ & & & \\ \text { Yes } & N o & t \text {-stat. } & p \text {-value } \\ 3.77 \% & 0.33 \% & -4.3800 & 0.0000 \\ 336 & 396 & & \\ & & & \\ \text { Yes } & N o & t \text {-stat. } & p \text {-value } \\ 0.08 \% & 0.00 \% & -3.1191 & 0.0200 \\ 336 & 396 & & \end{array}$

Note: Test of equality of variance rejected in all cases. All t-tests conducted without assuming equality of variance. 
Table 6. Determinants of the Incidence of Theft

The dependent variable is the value of annual losses due to theft divided by total annual sales. Tobit estimates reported.

\begin{tabular}{|c|c|c|c|c|c|c|c|}
\hline $\begin{array}{l}\text { Exposure factors } \\
\text { Night storage at sales location }\end{array}$ & Yes $=1$ & Coef. & t-stat. & $\begin{array}{l}\text { Coef. } \\
0.465\end{array}$ & $\begin{array}{l}\text { t-stat. } \\
4.356 \text { a }\end{array}$ & $\begin{array}{l}\text { Coef. } \\
0.297\end{array}$ & $\begin{array}{l}\text { t-stat. } \\
2.370 \mathrm{p}\end{array}$ \\
\hline Storage capacity & $\log (x+1)$ & & & 0.020 & $1.577 \mathrm{a}$ & 0.040 & $2.204 p$ \\
\hline \multicolumn{8}{|l|}{ Trader characteristics } \\
\hline Total sales & Value & 0.029 & $2.274 p$ & -0.008 & $-0.539 p$ & 0.008 & 0.603 \\
\hline Years of schooling & Value & 0.000 & 0.108 & -0.002 & -0.439 & -0.005 & -1.094 \\
\hline Years of experience & $\log (x+1)$ & -0.021 & -0.887 & -0.023 & -0.980 & -0.038 & -1.585 \\
\hline \multicolumn{8}{|l|}{ Location dummies } \\
\hline In capital city & Yes $=1$ & -0.082 & -1.136 & -0.079 & -1.176 & -0.044 & -0.614 \\
\hline In another urban location & Yes $=1$ & -0.031 & -0.844 & -0.030 & -0.829 & -0.022 & -0.600 \\
\hline In Vakinankaratra region & Yes $=1$ & -0.091 & -1.225 & -0.074 & -1.073 & -0.051 & -0.693 \\
\hline In Fianar/hauts plateaux region & Yes $=1$ & -0.108 & -1.473 & -0.095 & -1.372 & -0.081 & -1.119 \\
\hline In Fianar/cotes et falaise region & Yes $=1$ & -0.100 & -1.291 & -0.068 & -0.921 & 0.016 & 0.200 \\
\hline In Majunga/plaines region & Yes $=1$ & -0.102 & -1.215 & 0.242 & 2.225 & 0.233 & 1.738 \\
\hline In Majunga/plateaux region & Yes $=1$ & -0.079 & -1.031 & 0.122 & 1.415 & 0.169 & 1.455 \\
\hline Intercept & & -0.463 & -2.912 & -0.508 & -2.709 & -0.541 & -2.995 \\
\hline Selection-term & & 0.181 & & 0.169 & & 0.176 & \\
\hline Number of observations & & 672 & & 672 & & 672 & \\
\hline$\%$ zero observations & & $92 \%$ & & $92 \%$ & & $92 \%$ & \\
\hline Pseudo R-square & & 0.0619 & & 0.2901 & & 0.1416 & \\
\hline
\end{tabular}

Notes: $a=$ actual value used as regressor. $p=$ predicted value used as regressor. See text for details. 
Table 7. Determinants of the Incidence of Late Delivery by Suppliers

The dependent variable is the proportion of late deliveries in total purchase transactions.

Tobit estimates reported.

\begin{tabular}{|c|c|c|c|c|c|c|c|}
\hline $\begin{array}{l}\text { Exposure factors } \\
\text { Respondent places orders } \\
\text { Trader characteristics }\end{array}$ & Yes $=1$ & Coef. & t-stat. & Coef. & t-stat. & $\begin{array}{l}\text { Coef. } \\
1.085\end{array}$ & $\begin{array}{l}\text { t-stat. } \\
3.551 \mathrm{p}\end{array}$ \\
\hline Total sales & Value & -0.005 & $-0.160 p$ & -0.044 & $-1.345 p$ & -0.006 & -0.178 \\
\hline Years of schooling & Value & 0.009 & 0.868 & 0.004 & 0.451 & 0.002 & 0.158 \\
\hline Years of experience & $\log (x+1)$ & -0.036 & -0.730 & -0.009 & -0.199 & -0.033 & -0.664 \\
\hline \# relatives in agricultural trade & $\log (x+1)$ & 0.153 & 2.590 & 0.002 & 0.031 & 0.060 & 0.976 \\
\hline \# suppliers known personally & $\log (x+1)$ & 0.071 & 1.497 & 0.019 & 0.401 & -0.008 & -0.156 \\
\hline Location dummies & & & & & & & \\
\hline Antananarivo & Yes $=1$ & 0.024 & 0.147 & 0.061 & 0.435 & 0.135 & 0.783 \\
\hline Other urban location & Yes $=1$ & -0.044 & -0.503 & 0.082 & 0.937 & -0.020 & -0.221 \\
\hline In Vakinankaratra region & Yes $=1$ & -0.137 & -0.834 & -0.208 & -1.498 & -0.044 & -0.255 \\
\hline In Fianar/hauts plateaux region & Yes $=1$ & -0.323 & -1.850 & -0.311 & -2.095 & -0.125 & -0.665 \\
\hline In Fianar/cotes et falaise region & Yes $=1$ & -0.298 & -1.612 & -0.226 & -1.381 & -0.077 & -0.385 \\
\hline In Majunga/plaines region & Yes $=1$ & -0.330 & -1.520 & -0.413 & -2.043 & -0.209 & -0.940 \\
\hline In Majunga/plateaux region & Yes $=1$ & -2.364 & & -1.813 & & -2.222 & \\
\hline Intercept & & -0.503 & -1.298 & 0.604 & 1.650 & -0.621 & -1.576 \\
\hline Selection-term & & 0.415 & & 0.253 & & 0.408 & \\
\hline Number & & 669 & & 100 & & 669 & \\
\hline$\%$ zero observations & & $91 \%$ & & $43 \%$ & & $91 \%$ & \\
\hline Pseudo R-square & & 0.1908 & & 0.350 & & 0.237 & \\
\hline
\end{tabular}

Notes: $\mathrm{a}=$ late deveries not observed when no orders are placed. $\mathrm{p}=$ predicted value used as regressor. See text for details. 
Table 8. Determinants of the Incidence of Deficient Quality Deliveries by Suppliers

The dependent variable is the proportion of deficient quality deliveries in total purchase transactions. Tobit estimates reported.

\begin{tabular}{|c|c|c|c|c|c|c|c|}
\hline $\begin{array}{l}\text { Exposure factors } \\
\text { Verification of quality } \\
\text { Trader characteristics }\end{array}$ & Code $(c)$ & Coef. & t-stat. & $\begin{array}{l}\text { Coef. } \\
0.045\end{array}$ & $\begin{array}{l}\text { t-stat. } \\
1.207 \mathrm{a}\end{array}$ & $\begin{array}{l}\text { Coef. } \\
0.024\end{array}$ & $\begin{array}{l}\text { t-stat. } \\
0.642 \mathrm{p}\end{array}$ \\
\hline Total sales & Value & 0.007 & $0.306 p$ & 0.005 & $0.214 p$ & 0.004 & 0.159 \\
\hline Years of schooling & Value & -0.008 & -1.124 & -0.008 & -1.158 & -0.008 & -1.170 \\
\hline Years of experience & $\log (x+1)$ & -0.063 & -1.870 & -0.064 & -1.895 & -0.061 & -1.804 \\
\hline \# relatives in agricultural trade & $\log (x+1)$ & 0.160 & 3.988 & 0.167 & 4.123 & 0.178 & 3.624 \\
\hline \# suppliers known personally & $\log (x+1)$ & 0.039 & 1.190 & 0.044 & 1.353 & 0.043 & 1.303 \\
\hline Location dummies & & & & & & & \\
\hline Antananarivo & Yes $=1$ & -0.028 & -0.243 & -0.033 & -0.291 & -0.044 & -0.373 \\
\hline Other urban location & Yes $=1$ & -0.020 & -0.350 & -0.014 & -0.247 & -0.008 & -0.137 \\
\hline In Vakinankaratra region & Yes $=1$ & 0.097 & 0.842 & 0.096 & 0.841 & 0.080 & 0.685 \\
\hline In Fianar/hauts plateaux region & Yes $=1$ & -0.370 & -2.965 & -0.370 & -2.976 & -0.384 & -3.035 \\
\hline In Fianar/cotes et falaise region & Yes $=1$ & -0.236 & -1.857 & -0.238 & -1.883 & -0.253 & -1.955 \\
\hline In Majunga/plaines region & Yes $=1$ & -0.507 & -3.049 & -0.495 & -2.983 & -0.490 & -2.920 \\
\hline In Majunga/plateaux region & Yes $=1$ & -2.163 & & -2.145 & & -2.137 & \\
\hline Intercept & & -0.157 & -0.614 & -0.197 & -0.769 & -0.089 & -0.322 \\
\hline Selection-term & & 0.354 & & 0.352 & & 0.353 & \\
\hline Number of observations & & 669 & & 669 & & 669 & \\
\hline \% zero observations & & $79 \%$ & & $79 \%$ & & $79 \%$ & \\
\hline Pseudo R-square & & 0.327 & & 0.330 & & 0.328 & \\
\hline
\end{tabular}

Notes: $a=$ actual value used as regressor. $p=$ predicted value used as regressor. See text for details.

Code (c) as follows: $1=$ always verifies quality; $2=$ often; $3=$ sometimes; $4=$ rarely; $5=$ never. 
Table 9. Determinants of the Incidence of Late Payment by Clients

The dependent variable is the proportion of late payments in total sales transactions. Tobit estimates reported.

\begin{tabular}{|c|c|c|c|c|c|c|c|}
\hline $\begin{array}{l}\text { Exposure factors } \\
\text { Credit sales in total sales } \\
\text { Trader characteristics }\end{array}$ & Share & Coef. & t-stat. & $\begin{array}{l}\text { Coef. } \\
0.433\end{array}$ & $\begin{array}{l}\text { t-stat. } \\
7.579 \text { a }\end{array}$ & $\begin{array}{l}\text { Coef. } \\
0.189\end{array}$ & $\begin{array}{l}\text { t-stat. } \\
2.491 \mathrm{p}\end{array}$ \\
\hline Total sales & Value & 0.026 & $2.519 p$ & 0.001 & $0.060 \mathrm{p}$ & 0.018 & 1.684 \\
\hline Years of schooling & Value & 0.000 & 0.138 & 0.001 & 0.318 & -0.000 & -0.111 \\
\hline Years of experience & $\log (x+1)$ & 0.024 & 1.401 & 0.007 & 0.431 & 0.008 & 0.463 \\
\hline \# relatives in agricultural trade & $\log (x+1)$ & 0.028 & 1.428 & 0.024 & 1.244 & 0.030 & 1.556 \\
\hline \# clients known personally & $\log (x+1)$ & 0.016 & 1.254 & 0.014 & 1.085 & 0.002 & 0.161 \\
\hline Location dummies & & & & & & & \\
\hline Antananarivo & Yes $=1$ & -0.201 & -3.370 & -0.140 & -2.402 & -0.149 & -2.356 \\
\hline Other urban location & Yes $=1$ & -0.057 & -2.135 & -0.031 & -1.180 & -0.047 & -1.761 \\
\hline In Vakinankaratra region & Yes $=1$ & -0.115 & -1.946 & -0.050 & -0.869 & -0.066 & -1.051 \\
\hline In Fianar/hauts plateaux region & Yes $=1$ & -0.279 & -4.621 & -0.265 & -4.509 & -0.249 & -4.062 \\
\hline In Fianar/cotes et falaise region & Yes $=1$ & -0.247 & -3.995 & -0.223 & -3.711 & -0.215 & -3.412 \\
\hline In Majunga/plaines region & Yes $=1$ & -0.298 & -4.169 & -0.217 & -3.100 & -0.227 & -2.955 \\
\hline In Majunga/plateaux region & Yes $=1$ & -0.332 & -4.842 & -0.246 & -3.658 & -0.255 & -3.407 \\
\hline Intercept & & -0.263 & -2.126 & -0.087 & -0.699 & -0.171 & -1.330 \\
\hline Selection-term & & 0.192 & & 0.184 & & 0.192 & \\
\hline Number of observations & & 672 & & 672 & & 672 & \\
\hline \% zero observations & & $69 \%$ & & $69 \%$ & & $69 \%$ & \\
\hline Pseudo R-square & & 0.313 & & 0.485 & & 0.330 & \\
\hline
\end{tabular}

Notes: $a=$ actual value used as regressor. $p=$ predicted value used as regressor. See text for details. 
Table 10. Determinants of the Incidence of Non-Payment by Clients

The dependent variable is the proportion of non-payments in total sales transactions. Tobit estimates reported.

\begin{tabular}{|c|c|c|c|c|c|c|c|}
\hline $\begin{array}{l}\text { Exposure factors } \\
\text { Credit sales in total sales } \\
\text { Trader characteristics }\end{array}$ & Share & Coef. & t-stat. & $\begin{array}{l}\text { Coef. } \\
0.013\end{array}$ & $\begin{array}{l}\text { t-stat. } \\
1.762 \text { a }\end{array}$ & $\begin{array}{r}\text { Coef. } \\
-0.003\end{array}$ & $\begin{array}{l}\text { t-stat. } \\
-0.330 \mathrm{p}\end{array}$ \\
\hline Total sales & Value & 0.002 & $1.910 \mathrm{p}$ & 0.002 & $1.237 \mathrm{p}$ & 0.003 & 1.916 \\
\hline Years of schooling & Value & 0.001 & 1.723 & 0.001 & 1.817 & 0.001 & 1.746 \\
\hline Years of experience & $\log (x+1)$ & 0.000 & 0.203 & 0.000 & 0.059 & 0.001 & 0.307 \\
\hline \# relatives in agricultural trade & $\log (x+1)$ & 0.005 & 2.194 & 0.005 & 2.146 & 0.005 & 2.203 \\
\hline \# clients known personally & $\log (x+1)$ & -0.002 & -1.271 & -0.002 & -1.293 & -0.002 & -0.963 \\
\hline Location dummies & & & & & & & \\
\hline Antananarivo & Yes $=1$ & -0.009 & -1.597 & -0.007 & -1.237 & -0.010 & -1.593 \\
\hline Other urban location & Yes $=1$ & -0.003 & -0.770 & -0.002 & -0.555 & -0.003 & -0.802 \\
\hline In Vakinankaratra region & Yes $=1$ & -0.015 & -2.431 & -0.013 & -2.067 & -0.016 & -2.368 \\
\hline In Fianar/hauts plateaux region & Yes $=1$ & -0.023 & -3.588 & -0.022 & -3.394 & -0.024 & -3.536 \\
\hline In Fianar/cotes et falaise region & Yes $=1$ & -0.024 & -3.456 & -0.023 & -3.279 & -0.025 & -3.415 \\
\hline In Majunga/plaines region & Yes $=1$ & -0.025 & -2.818 & -0.023 & -2.504 & -0.027 & -2.745 \\
\hline In Majunga/plateaux region & Yes $=1$ & -0.026 & -3.151 & -0.024 & -2.798 & -0.027 & -2.996 \\
\hline Intercept & & -0.038 & -2.506 & -0.034 & -2.162 & -0.040 & -2.469 \\
\hline Selection-term & & 0.015 & & 0.015 & & 0.015 & \\
\hline Number of observations & & 672 & & 672 & & 672 & \\
\hline$\%$ zero observations & & $93 \%$ & & $93 \%$ & & $93 \%$ & \\
\hline Pseudo R-square & & -3.436 & & -3.631 & & -3.442 & \\
\hline
\end{tabular}

Notes: $a=$ actual value used as regressor. $p=$ predicted value used as regressor. See text for details. 


\section{Table 11. Recourse to Legal Institutions}

\section{A. Theft:}

Trader sought help of the police $\quad 37.5 \%$

Trader went to court $\quad 10.7 \%$

Number of observations: 57

B. Disputes with clients and suppliers:

Traders who ever used the following in a dispute with client or supplier:

A third party as mediator or arbitrator

$14.0 \%$

The police

$4.0 \%$

A lawyer

$0.6 \%$

A court

$0.7 \%$

Number of observations:

729

Conflict resolution methods used during the last incidence of:

1. Breach of contract by supplier:

Trader negotiated directly with supplier $\quad 86.0 \%$

Trader sought help of mediator $\quad 3.4 \%$

Trader sought help of lawyer $\quad 0.0 \%$

Trader threatened to go to the police $\quad 0.0 \%$

Trader threatened to go to court $\quad 0.6 \%$

Number of observations: $\quad 178$

2. Breach of contract by client:

Trader negotiated directly with client $\quad 93.6 \%$

Trader sought help of mediator $\quad 9.1 \%$

Trader sought help of lawyer $\quad 0.5 \%$

Trader threatened to go to the police $3.6 \%$

Trader threatened to go to court $\quad 0.9 \%$

Number of observations: $\quad 220$ 
Table 12. Determinants of Choice of Dispute Resolution Method

Dispute with:

Supplier

Dependent variable

Value

Characteristics of transaction:

Case of deficient quality

Length of relationship

Amount paid (supplier)/ due (client)

Characteristic of trader

Total sales

\# relatives in agricultural trade

\# suppliers/clients known personally

Intercept

Number of observations

Pseudo R-square
Direct negotiation

Yes $=1$

Coef. $\quad$ stat

Yes $=1 \quad 0.196 \quad 0.616$

$\log (x+1)$

$\log (x+1)$

$\log (x)$

$\log (x+1)$

$\log (x+1)$

$0.216 \quad 4.418$

$0.055 \quad 1.991$

$-0.118 \quad-0.961$

$-0.234 \quad-1.058$

$0.332 \quad \mathbf{1 . 7 2 9}$
$0.918 \quad 0.666$

180

0.229
246

$0.522 \quad 0.215$

246

$0.522 \quad 0.215$

Dispute with:

\section{Client}

Direct negotiation Use of Mediator

Yes $=1$ Yes $=1$

Coef. z stat Coef. $\quad z$ stat

n.a. n.a.

$\begin{array}{llll}0.072 & 1.185 & 0.738 & \mathbf{3 . 2 7 3}\end{array}$

$\begin{array}{llll}0.227 & 4.974 & -0.094 & -0.968\end{array}$

$\begin{array}{llll}0.132 & 1.057 & 0.231 & 1.991\end{array}$

$\begin{array}{llll}-0.792 & \mathbf{- 3 . 4 5 7} & -0.505 & \mathbf{- 1 . 9 2 7}\end{array}$

$\begin{array}{llll}0.383 & 1.846 & 0.104 & 0.531\end{array}$

$\begin{array}{llll}-3.163 & \mathbf{- 2 . 1 4 7} & -7.512 & \mathbf{- 3 . 8 4 9}\end{array}$ 
Table 13. Determinants of Conflict Resolution with Suppliers

Probit estimates reported.

\section{Method of dispute resolution}

Direct negotiations with supplier Yes=1

\section{Dispute is resolved (Yes=1)}

Coef. t-stat.

Characteristics of transaction

Dispute is about quality

Days of trade with supplier

Amount already paid to supplier $\log (x+1)$

Characteristics of trader

Total annual sales

\# relatives in agricultural trade

\# suppliers known personally

Intercept

Number of observations

Pseudo R-square
Yes $=1$

$\log (x+1)$

Value
$\log (x+1)$
$\log (x+1)$

$-0.711 \quad-1.912$

0.751

$-0.037-1.454$

$0.299 \quad 2.177$

$-0.333-1.623$

$0.364 \quad \mathbf{1 . 6 8 0}$

$-2.012-1.278$

167

0.177
Coef. t-stat. $2.805 \quad 4.585$

$-0.538-1.335$

$-0.011-0.185$

$-0.040-1.363$

\section{$\begin{array}{ll}0.458 & 2.747\end{array}$}

$-0.326-1.311$

$\begin{array}{ll}0.175 & 0.663\end{array}$

$-5.879-2.861$

167

0.412
Trade is resumed (Yes $=1$ ) Coef. t-stat. Coef. t-stat. $0.793 \quad \mathbf{1 . 8 8 7}$

$\begin{array}{rrrr}0.191 & 0.596 & 0.232 & 0.706 \\ -0.021 & -0.414 & -0.053 & -0.962 \\ -0.025 & -0.933 & -0.027 & -1.022\end{array}$

$0.259 \quad 1.798$

$0.304 \quad 1.982$

$0.076 \quad 0.328$

$\begin{array}{ll}0.060 & 0.286\end{array}$

$-2.645-1.523$

171

0.081

Note: Results give the outcome of a contractual dispute conditional on a dispute having occurred. 
Table 14. Determinants of Conflict Resolution with Clients

Probit estimates reported.

\begin{tabular}{|c|c|c|c|c|c|c|c|c|c|}
\hline \multirow{3}{*}{$\begin{array}{l}\text { Method of dispute resolution } \\
\text { Direct negotiations with supplier }\end{array}$} & & \multicolumn{4}{|c|}{ Dispute is resolved (Yes=1) } & \multicolumn{4}{|c|}{ Trade is resumed (Yes $=1)$} \\
\hline & & Coef. & t-stat. & Coef. & t-stat. & Coef. & t-stat. & Coef. & t-stat. \\
\hline & & & & 2.375 & 3.851 & & & 1.680 & 3.743 \\
\hline Recourse to third-party mediato & & & & -1.042 & -2.943 & & & -0.925 & -2.650 \\
\hline Recourse to lawyer & & & & -0.536 & -0.968 & & & -2.014 & -2.805 \\
\hline \multicolumn{10}{|l|}{ Characteristics of transaction } \\
\hline Days of trade with client & $\log (x+1)$ & -0.028 & -0.586 & -0.016 & -0.299 & -0.064 & -1.366 & -0.065 & -1.227 \\
\hline Value of the sales transaction & $\log (x+1)$ & 0.048 & 0.783 & 0.052 & 0.758 & -0.056 & -1.381 & -0.136 & -2.864 \\
\hline \multicolumn{10}{|l|}{ Characteristics of trader } \\
\hline Total annual sales & Value & 0.040 & 0.457 & 0.031 & 0.313 & 0.033 & 0.413 & 0.079 & 0.913 \\
\hline \# relatives in agricultural trade & $\log (x+1)$ & -0.614 & -3.555 & -0.571 & -2.696 & -0.481 & -2.937 & -0.501 & -2.604 \\
\hline \# clients known personally & $\log (x+1)$ & 0.603 & 3.697 & 0.713 & 3.781 & 0.397 & 2.617 & 0.491 & 2.810 \\
\hline Intercept & & -0.975 & -0.923 & -3.288 & -2.589 & 0.746 & 0.792 & -0.402 & -0.393 \\
\hline Numbe & & 22 & & 222 & & 235 & & 231 & \\
\hline Pseudo R-square & & 0.122 & & 0.286 & & 0.077 & & 0.244 & \\
\hline
\end{tabular}

Note: Results give the outcome of a contractual dispute conditional on a dispute having occurred. 


\section{Table 15. Trade Credit}

A. Procedure to obtain/grant supplier credit

Purchase several times

in which case, how many times

Be referred by another trader

Provide a bank guarantee or give a deposit

Fill in forms

\begin{tabular}{rr} 
With & \multicolumn{1}{c}{ With } \\
Suppliers & Clients \\
$83.0 \%$ & $72.4 \%$ \\
7 & 9 \\
$11.3 \%$ & $17.1 \%$ \\
$1.5 \%$ & $2.4 \%$ \\
$0.5 \%$ & $1.8 \%$ \\
& \\
Supplier & Client \\
$77.7 \%$ & $88.9 \%$ \\
$1.6 \%$ & $4.4 \%$ \\
$0.5 \%$ & $1.8 \%$ \\
& \\
Supplier & Client \\
$11.3 \%$ & $20.9 \%$ \\
$40.2 \%$ & $58.7 \%$ \\
$31.4 \%$ & $15.4 \%$ \\
$17.0 \%$ & $4.9 \%$ \\
& \\
195 & 342
\end{tabular}

Number of observations

Action taken in case of non payment

Stop deliveries

Go to the police

Go to court

C. Loss of credit with other suppliers

Very unlikely

Unlikely

Likely

Very likely

$195 \quad 342$

Note: Data collected only from respondents who receive or give supplier cred 
Table 16. Screening of Potential Trade Credit Recipients

\section{A. Source of information on client}

Obtain information from client himself/herself $\quad 95.9 \%$

Obtain information from other traders

$24.0 \%$

Obtain information from other sources

$12.3 \%$

Obtain information from client's bank

B. Information sharing with other traders about bad clients

Once a day

Once a week

$1.5 \%$

Once a month

$1.7 \%$

Occasionally

$10.1 \%$

Never

$62.6 \%$

$24.1 \%$

Number of observations:

344

Note: Data collected only from respondents who give credit to clients. 
Appendix A. Instrumenting Regression for Total Sales

A. Capital and equipment

Working capital

Dummy if subsidiary

Value of equipment

Storage capacity

Number of vehicles

Utilization of telephone

B. Labor and management

Age of trader

Sexe of trader

Manpower (in months/year)

$\%$ family labor in total labor force

Dummy if full time trader

Dummy if trader all year round

Years of schooling of owner/manager

Years of experience in agricultural trade

Speaks another language

C. Social capital

Number of relatives in agric. trade

Number of traders known

Number of people who can help

Number of suppliers known personally

Number of clients known personally

D. Entrepreneur's wealth

Value of home

E. Entrepreneur's attitude

Propensity to invest in business

Propensity to save

Propensity to spend on durables Individualism

Altruism

F. Entrepreneur's family background

Father has primary education

Mother has primary education

Father has secondary education

Mother has secondary education

Father's years of trade experience

Mother's years of trade experience

Father's years of ag. trade exper.

Mother's years of ag. trade exper.

Number of adult brothers

Number of adult sisters

F. Shocks

Aggregate sales shock

G. Location

In capital city

In another city

In Vakinankaratra region

In Fianar/hauts plateaux region

In Fianar/cotes et falaise region

In Majunga/plaines region

In Majunga/plateaux region

Intercept

\begin{tabular}{|c|c|c|}
\hline & Coef. & t stat. \\
\hline $\log (x)$ & 0.209 & 6.720 \\
\hline Yes $=1$ & 1.072 & 5.018 \\
\hline $\log (x+1)$ & 0.042 & 1.656 \\
\hline $\log (x+1)$ & 0.174 & 3.932 \\
\hline $\log (x+1)$ & -0.210 & -0.955 \\
\hline Yes $=1$ & 0.368 & 2.613 \\
\hline Value & 0.010 & 1.880 \\
\hline Male $=1$ & -0.115 & -1.269 \\
\hline $\log (x)$ & 0.515 & 5.394 \\
\hline share & -0.255 & -1.412 \\
\hline$Y e s=1$ & 0.138 & 0.909 \\
\hline$Y e s=1$ & 0.394 & 2.833 \\
\hline Level & 0.026 & 1.614 \\
\hline $\log (x+1)$ & 0.020 & 0.268 \\
\hline$Y e s=1$ & -0.156 & -1.373 \\
\hline $\log (x+1)$ & -0.225 & -2.186 \\
\hline $\log (x+1)$ & 0.137 & 1.994 \\
\hline $\log (x+1)$ & 0.307 & 3.541 \\
\hline $\log (x+1)$ & 0.053 & 0.852 \\
\hline $\log (x+1)$ & 0.104 & 1.695 \\
\hline $\log (x+1)$ & -0.000 & -0.683 \\
\hline Index & -0.145 & -2.448 \\
\hline Index & -0.103 & -2.665 \\
\hline Index & -0.023 & -0.593 \\
\hline Index & -0.063 & -1.048 \\
\hline Index & -0.016 & -0.305 \\
\hline$Y e s=1$ & -0.045 & -0.362 \\
\hline$Y e s=1$ & 0.071 & 0.567 \\
\hline$Y e s=1$ & 0.196 & 1.314 \\
\hline Yes $=1$ & 0.056 & 0.305 \\
\hline $\log (x+1)$ & 0.110 & 1.183 \\
\hline $\log (x+1)$ & -0.124 & -1.272 \\
\hline $\log (x+1)$ & -0.050 & -0.411 \\
\hline $\log (x+1)$ & 0.003 & 0.024 \\
\hline $\log (x+1)$ & 0.006 & 0.197 \\
\hline $\log (x+1)$ & 0.081 & 2.608 \\
\hline Ratio & 0.161 & 1.985 \\
\hline Yes $=1$ & -0.566 & -1.591 \\
\hline$Y e s=1$ & 0.272 & 2.240 \\
\hline$Y e s=1$ & -0.457 & -1.384 \\
\hline$Y e s=1$ & -1.140 & -3.100 \\
\hline$Y e s=1$ & -1.043 & -2.786 \\
\hline$Y e s=1$ & -0.388 & -0.979 \\
\hline \multirow[t]{2}{*}{ Yes $=1$} & -0.939 & -2.404 \\
\hline & 6.55 & 10.46 \\
\hline
\end{tabular}

Number of observations 
Appendix B: Determinants of Exposure to Risk

Dependent variable:

Estimator:

A. Wealth

Value of home

B. Human capital

Age of trader

Sexe of trader

Years of schooling

Years of trade experience

C. Social network capital

\# relatives in ag. trade

\# traders known

\# people who can help

\# suppliers known pers.

\# clients known pers.

D. Personal traits

Propensity to invest in business

Propensity to save

Propensity to spend on durables

Individualism

Altruism

E. Family background

Father has primary education

Mother has primary education

Father has high school educ.

Mother has high school educ.

Father's years of trade experience

Mother's years of trade experience

Father's years of ag. trade exper.

Mother's years of ag. trade exper.

Number of adult brothers

Number of adult sisters

F. Location

In capital city

In another urban location

In Vakinankaratra region

In Fianar/hauts plateaux region

In Fianar/cotes et falaise region

In Majunga/plaines region

In Majunga/plateaux region

Value

Male $=1$

Value

$\log (x+1)$

$\log (x+1)$

$\log (x+1)$

$\log (x+1)$

$\log (x+1)$

$\log (x+1)$

Index

Index

Index

Index

Index

Yes $=1$

Yes $=1$

Yes $=1$

Yes $=1$

$\log (x+1)$

$\log (x+1)$

$\log (x+1)$

$\log (x+1)$

Value

Value

Yes $=1$

Yes $=1$

Yes $=1$

Yes $=1$

Yes $=1$

Yes $=1$

Yes $=1$

sure to Risk

Storage

capacity

$\log (x+1)$

Tobit

$\begin{array}{lll} & \text { Coef. } & \text { t-stat. } \\ \text { Value } & 0.000 & \mathbf{8 . 0 5 5}\end{array}$

$0.033 \quad 5.292$

$-0.190$

0.038

$-1.777$

0.043

0.478

$0.038 \quad 0.306$

$-0.069$

0.060

0.180

$-0.849$

0.576

0.074

2.473

1.019

$0.182 \quad 2.640$

$-0.010-0.219$

$-0.062-1.353$

$0.050 \quad 0.699$

$-0.040-0.646$

$0.091 \quad 0.614$

$-0.189-1.254$

$0.358 \quad 1.992$

0.230

1.992

0.002

0.013

0.026

$-0.070$

0.212

0.114

$-0.467$

0.775

$-0.076 \quad-2.125$

$-0.008-0.200$

0.379

Intercept

Second intercept (ordered probit only)

Third intercept (ordered probit only)

Selection-term (tobit only)

\section{$-0.139-0.986$}

$-0.139-0.986$

$0.315 \quad 0.804$

$\begin{array}{ll}0.389 & 0.913\end{array}$

$-0.420-0.979$

$-1.044 \quad-2.282$

$-0.240 \quad-0.555$

$-0.420 \quad-0.687 \quad 4.546$

1.289

Overnight
storage
Yes $=1$
Probit

Placement of
orders

Yes=1

Probit

Coef. $t$-stat.

0.000

2.427

Coef

coef. t-stat.

$0.019 \quad 1515$

0.019
-0.068

0.049

1.515

0.017

7

2.075

1.363

0.071

0.384

0.115

0.419

$-0.093$

0.432

$-0.546$

2.127

0.154
-0.229

0.013

0.096

0.188

1.285

0.206

$-0.127$

1.598

$-0.038-0.422$

$-0.150-1.068$

0.373

2.743

0.155

$-0.590$

0.500

0.046

-1.849
0.132

0.461

$-0.344$

$-0.283$

2.439

$-1.688$

$-0.751-3.062$

0.584

2.523

0.125

1.732

$-0.087-1.215$

0.04

$-0.298$

0.007

1.236

0.059

$-4.614$

$-5.033$

0.325

1.022

$-4.713$

$-5.065$

$-6.029$

$-5.117$

$-6.079$

$-9.513$

$-8.942$

$-9.031$

4.546

1.058

0.011

0.329

0.030

$-0.085$

3.409

0.327

$-0.07$

$-0$.

0.829

$\begin{array}{ll}0.056 & 1.021\end{array}$

$-0.043-0.783$

$0.118 \quad 1.403$

$-0.261$

$-3.288$

$\begin{array}{ll}0.301 & 1.571\end{array}$

$-0.326$

$-1$.

$-1.726$

0.556

$-0.422$

2.446

2.446
-1.507

$0.164 \quad 1.280$

0.101

0.628

$-0.175-1.117$

$-0.011-0.232$

$-0.055$

$-1.187$

0.213

0.443

$-0.010$

$-0.055$

0.322

$-0.024$

$-0.048$

$-0.344$

400

0.727

$-0.212$

$-0.113$

$-2.247$

$-0.363$

0.849

1.330

696

0.1224

704

0.7391

703

0.1471

700

0.2419

0.146

0.000

0.369

$-0.189$

0.341

0.184

373

0.042

0.097

.357
0.265

0.265

0.198

0.955

413

$-1.933$

.362

0.707

0.001

1.256

$-1.380$

2.552

1.085

$-2.251$

1.467

$-0.805$

$-0.152$

$-1.943$

0.433

0.088

0.304 